Beate Collet \& Estelle Bonnet

\title{
Decisions concerning job-related spatial mobility and their impact on family careers in France and Germany $^{1}$
}

\section{Entscheidungen zu berufsbedingter räumlicher Mobilität und ihre Auswirkungen auf Familienkarrieren in Frankreich und Deutschland}

\begin{abstract}
:
Job-related spatial mobility raises questions about women's and men's professional life. It does not always accompany a specific job or a promotion; it may also arise as the consequence of being in a dual-career couple. We will study how the decision is handled by bi-active couples, compared to couples who live according to the more classical 'male breadwinner model', and how other sociodemographic factors, especially the presence of children, influence the decision in favour of mobility. We will compare data on France and Germany drawn from the European Survey Job Mobilities and Family Lives (2007) realised in six European countries. Women's employment rates and family policies are not the same in the two countries. While France has for several years provided solutions to help women remain in the labour force while raising children, Germany only recently abandoned a mother-centred family policy which pushed women to stay at home while raising their children. Statistical data will be completed by results from two qualitative studies to see more precisely how job mobility is experienced concretely. One study was realised in France in 2006. Results from the other study in Germany in 2001 will be reported. Both place the accent on mobile people who spend several days a week away from home. A typology of 'family careers', developed in the French study and ap-
\end{abstract}

\begin{abstract}
Zusammenfassung:
Beruflich bedingte räumliche Mobilität stellt die Frage nach der Erwerbsarbeit von Männern und Frauen. Es geht dabei aber nicht nur um die Entscheidung für einen bestimmten Beruf oder für einen Karriereschritt. Mobilität kann auch eine Folge von Doppelerwerbstätigkeit eines Paares sein. Wir gehen der Frage nach, wie die Entscheidung bei bi-aktiven Paaren im Verhältnis zu mono-aktiven Paaren getroffen wird und inwieweit andere soziodemographische Faktoren, besonders die Anwesenheit von Kindern in der Familie, Mobilitätsentscheidungen beeinflussen. Wir vergleichen deutsche und französische Daten, die in einer europäischen in sechs Ländern durchgeführten Studie Job Mobilities and Family Lives (2007) erhoben wurden. Die Erwerbstätigkeit von Frauen und die Familienpolitik sind in beiden Ländern relativ unterschiedlich. Während Frankreich schon seit Jahren Mütter mit konkreten Maßnahmen unterstützt, die es ermöglichen einer Erwerbstätigkeit nachzugehen, ist die $\mathrm{Fa}$ milienpolitik in Deutschland erst kürzlich von dem mutterzentrierten Modell abgekommen, dass Frauen darin unterstützte zuhause zu bleiben und die Kinder zu erziehen. Die statistische Auswertung wird vervollständigt durch Ergebnisse aus zwei qualitativen Studien. Die eine wurde 2006 in Frankreich durchgeführt. Die Ergebnisse der zweiten 2001 in Deutschland durchgeführten Studie
\end{abstract}

1 We express our thanks to Marilyne Goutagny, statistician (ISH Lyon), for her statistical support and Gabrielle Varro, sociologist, for the English translation. 
plied to the French and German data shows that couples differ with regard to the decision-making processes on mobility, which reveal different underlying partnership patterns.

Key words: job mobility, spatial mobility. FranceGermany comparison, family career, mobility decision process, conjugal negotiation werden berichtet. Beide Studien interessieren sich für Mobilitätsformen, die mehrere Tage Abwesenheit von zuhause verlangen. Eine Typologie unterschiedlicher „Familienkarrieren“, die im Rahmen der französischen Studie ausgearbeitet worden ist, wird hier zur Analyse des deutschen und französischen Materials herangezogen. Die Paare unterscheiden sich in Bezug auf den Entscheidungsprozess bezüglich der Mobilität und dieser wiederum hat unterschiedliche Partnerschaftskonzepte als Grundlage.

Schlagwörter: berufliche Mobilität, räumliche Mobilität, Familienbiographie, Entscheidung zur Mobilität, partnerschaftliche Aushandlungsprozesse

\section{Introduction}

For several years now, research has questioned the new forms of mobility connected to professional activity (Wagner 1989; Boltanski/Chiapello 1999; Schneider et al. 2002; Kaufmann 2002; Bonnet/Aubertel 2006). Whether in the form of long commutes, lengthy absences from home (several nights a week), professional travelling, international missions or moving to a new place of residence, mobility is likely to have effects on the equilibrium between the professional and private spheres (the couple, the family). Mobility also affects gender relations. Being more present today in the labour market, women may be mobile for professional reasons, and perhaps they are less inclined than in the past to follow their partner's career.

This article analyses the mobility decision process on the basis of the work-family balance among men and women living as couples and faced with a situation of geographic mobility demands. Its originality resides in the fact that we study the realities of job mobility not only from the individual standpoint but also from the couple's point of view. We assume that job related spatial mobility may be a decision which depends on how couples handle mobility demands. Since many are dual-earner couples, the question arises as to how they meet the demands of mobility, decide between the mobility of one or the other, and between professional and family consequences. Does the situation of mobility of one of the partners influence the other's activity? Is the career of one given priority to the detriment of the other's?

Mobility decisions of course involve structural constraints, mainly labour market and infrastructure, but they also require decisions on a more micro-sociological level in the interactional processes of the couple concerning family life. Though mobility may be an opportunity to access employment or to better one's professional situation, it may also be a solution that allows both partners to sustain an acceptable professional position. According to each partner's employment situation and activity, but also depending on their family situation and whether or not there are children involved, mobility leaves room for various forms of arbitration and for negotiations within the couple. The way the mobility 
decision is integrated in the "family career" may also depend on the conjugal conception the partners share.

\section{Methodological design}

Three studies carried out on the subject over the past years provide the quantitative and qualitative material which will permit us to answer these questions. We seize the opportunity here to buttress quantitative data from the European research programme Job Mobilities and Family Lives by life experiences collected while carrying out qualitative research among persons confronted by mobility in the course of their professional activity. In so doing, this article backs up the statistical data that permits us to grasp the breadth of the phenomena, with qualitative data that enhances the comprehensive dimension of our thinking on the issue by examining the couple's conjugal conceptions and negotiations in the light of mobility. The comparison between Germany and France will supplement our analysis by confronting the effects of the work-family balance in two different national contexts.

The analyses in this article are based on two sources of data and three sources of information. Some preliminary precisions are necessary because these studies do not have the same status and were conducted among different populations. The first source is Job Mobilities and Family Lives (JobMob, for short; http://www.jobmob-and-famlives.eu), a quantitative, representative survey carried out in 2007 in six European countries (Belgium, France, Germany, Poland, Spain and Switzerland). It focused on different types of job-related mobility experiences and their consequences on family life. More than 7,000 Europeans in the employable age span (25-54 years old) were interviewed, based on a standard questionnaire. The French survey reached 1,223 individuals, the survey in Germany 1,663 persons. The figures respect a certain regional distribution and were pondered according to sex, age and education level, referring to representative samples in both countries.

The survey distinguished four main types of mobility having a specific impact on family life: $L D C$ (Long-distance commuters) who must regularly make a return trip of more than two hours every working day; Recent Relocators who moved house for professional reasons (during the three years preceding the survey); Overnighters whose job calls for them to spend at least 60 nights a year away from home; ${ }^{2}$ and Multi-mobiles, who combine various types of mobility - they may, for instance, have recently moved house, while still shuttling back and forth two hours every day.

Persons not geographically mobile for professional reasons at the time of the survey were also placed into three categories: non-mobiles who had experienced mobility in the past but then stopped (Experienced); non-mobiles who explicitly rejected a mobility offer in the course of their career (Rejectors), and lastly, individuals who had never been confronted by a professional mobility demand or offer (Unchallenged).

2 Sixty nights a year is an average. Sometimes the person is away 2-3 nights a week on a regular basis except during holidays, or several months in a row as in the case of seasonal labourers. It was felt that 60 nights of absence were sufficient to affect family life. 
The second source of data is a qualitative study, Professional geographic mobility and family careers, which was carried out in France in 2005-2006 by Estelle Bonnet, Beate Collet and Béatrice Maurines, among a population who was mobile for professional reasons (Bonnet et al. 2006a). Individuals lived or had lived in couples, with or without children. One of the partners was away from home at least two nights a week. Fortyfive persons ( 21 men and 24 women) were interviewed by way of semi-directive, biographical interviews. There were 13 couples, of whom both partners participated in the study. Interviewees were between 35 and 55 years old. Those who were mobile were mainly high-level or mid-level executives. They occupied positions in the private sector (IT, consulting, commerce, banking) and the public sector (local or national civil service, teaching or nation-wide services such as the Postal Service or the utility company (Électricité de France). Being the authors of this study, we had access to all interview material. The typology proposed in the second part of this article has been elaborated on the basis of this material. ${ }^{3}$

As a third source of information, not as a source of analysis, results from the qualitative German study Berufsmobilität und Lebensform (Professional mobility and living arrangements) are reviewed and compared to the French data. The study was carried out in 2000/2001 by Norbert F. Schneider, Kerstin Hartmann and Ruth Limmer (Schneider et al. 2001). It consisted of a considerable number of standardized interviews (786) and indepth interviews (309) with persons experiencing different types of mobility, and with a control group of non-mobile persons. The group of Shuttles, comparable to the form of mobility studied in the French study, included 40 mobile persons, of whom 27 were in couples in which both partners were interviewed. The present article attempts a comparison with French job mobility reality by using results presented in the final research report produced by the authors (Schneider/Limmer/Ruckdeschel 2002).

Explicitly comparing two countries, neighbours in Europe and fundamental partners in the EU, seems particularly valuable. Close as to their economic choices, standard of living and infrastructures, these countries' family traditions and child-care systems are nevertheless quite different. In Germany, children's education is considered much more a family affair than a state institution (Ostner, 1994), collective child care (crèches, leisure centres) and school organization (full-time school schedules starting at the age of 3) are not as customary as in France (Martin 2010). ${ }^{4}$ These family factors, as well as the differences concerning French and German women's labour market involvement, ${ }^{5}$ may directly influence the job mobility realities in the two countries.

3 For a first presentation of the typology in French, cf. Bonnet/Collet 2009.

4 The considerable drop of the fertility rate (average number of children for a woman) in Germany (1.32; in France 1.98 in the same year, 2006, Eurostat) incited Germany to change its family policy, but recent reforms (increased family allowances, diversification of child-care for infants and longer days for school children) have as yet not shown their effects in the face of deeply ingrained cultural traditions (Klammer/Letablier 2008).

5 French and German women's rates of activity are practically identical, approx. $78 \%$ in each country (field: $25-54$ age group). The negligible difference between France and Germany is confirmed by Eurostat for 2006: 59\% in France and 62\% in Germany for the 15-64 age group. On the other hand, the JobMob survey, as well as Eurostat, show that French women work full time more often than German women ( $53 \%$ vs. $43 \%)$. 
In a first section, this article will account for the different configurations of mobility among couples in Germany and in France, and analyse the social characteristics of couples in situations of mobility (age, diplomas, activity, family situations with or without the presence of children, etc.) and the types of mobility which are theirs. In a second section, to carry out our comprehensive analysis, we will present a typology of conjugal conceptions that makes the couple's negotiations over mobility for professional reasons explicit.

\section{Couples in France and Germany facing job-related geographic mobility}

The quantitative survey Job Mobilities and Family Lives shows the level attained by jobrelated geographic mobility in Germany and France. First statistical analyses will concentrate on comparing the different forms of mobility in Germany and France on the basis of job involvement. In so doing, the first national differences in mobility reality that will appear may help us to interpret further differences in the decision-making process.

Job-related geographic mobility can be interpreted according to individual or conjugal rationales, for the mobility of one combines with the professional activity and mobility or non-mobility of the other. We will first account for the different types of mobility in both countries and the potential differences related to gender. We will then go on to "read" mobility from the standpoint of the conjugal entity, separating dual-career from monoactive couples and comparing mobile and non-mobile couples.

\subsection{Types of job-related geographic mobility, gender differences and family situations}

We open up the analysis with some of the facts we need to circumscribe the general situation (cf. Table 1). Job-related geographic mobility is more prevalent in Germany than in France: when total population is considered, it is superior by three points, by four when considering only the employed. The gap widens again (by five points) when considering solely persons working full-time. Germany stands out by a greater number of $L D C$ s (Longdistance commuters), Overnighters and Multi-mobiles. Recent Relocators are the only type of mobiles more numerous in France. In Germany people have more often recurrent forms of mobility, they live in fixed places and cover long distances to reach their working place. In France, where the mobility rate of the younger age-group is higher than the rate of the older people, we assume that many young employees relocate to live near their place of work. This fact is also confirmed by the higher rate of Experienced among the non-mobiles in France than in Germany.

There are several structural reasons for these basic national differences (labour market and distribution of the population in the country) but more individual reasons, depending on how people in the specific national context relate to their job, also come into play. ${ }^{6}$

6 To develop the reasons for these differences would be too much of a digression; for more general results, cf. Schneider/Meil 2008. 
Table 1: Types of mobility in Germany and in France according to the employment situation

\begin{tabular}{|c|c|c|c|c|c|c|}
\hline & $\begin{array}{c}\% \\
\text { of the total } \\
\text { sample }\end{array}$ & $\begin{array}{c}\text { Germany } \\
\% \\
\text { employed } \\
\text { persons }\end{array}$ & $\begin{array}{c}\% \\
\text { persons } \\
\text { working full } \\
\text { time }\end{array}$ & $\begin{array}{c}\% \\
\text { of the total } \\
\text { sample }\end{array}$ & $\begin{array}{c}\text { France } \\
\% \\
\text { employed } \\
\text { persons }\end{array}$ & $\begin{array}{c}\% \\
\text { persons } \\
\text { working full } \\
\text { time }\end{array}$ \\
\hline Mobiles (total) & 17 & 19 & 22 & 14 & 15 & 17 \\
\hline Long-distance commuters & 6 & 7 & 8 & 4 & 5 & 5 \\
\hline Overnighters & 5 & 5 & 7 & 4 & 5 & 5 \\
\hline Recent Relocators & 4 & 4 & 4 & 5 & 4 & 5 \\
\hline Multi-mobiles & 2 & 3 & 3 & 1 & 1 & 2 \\
\hline Non-mobiles (total) & 83 & 81 & 78 & 86 & 85 & 83 \\
\hline Experienced $^{A}$ & 32 & 31 & 32 & 35 & 36 & 38 \\
\hline Rejectors & 6 & 6 & 7 & 6 & 6 & 5 \\
\hline Unchallenged & 45 & 44 & 39 & 45 & 43 & 40 \\
\hline Total & 100 & 100 & 100 & 100 & 100 & 100 \\
\hline
\end{tabular}

A including persons who rejected mobility demands

Weight nation; total sample: $\mathrm{N}=1496$ for Germany and $\mathrm{N}=949$ for France: $\mathrm{V}=.061 ; \mathrm{p}=.175$.

Employed population: $\mathrm{N}=1261$ for Germany and $\mathrm{N}=803$ for France: $\mathrm{V}=.079 ; \mathrm{p}=.046$.

Population working full time: $N=925$ for Germany and $N=648$ for France: $V=.098 ; p=.019$.

Full time employment $=$ working at least 35 hours weekly

Source: From the European survey "Job Mobilities and Family Lives in Europe".

However, the two countries do not differ much if one takes into account both past and present mobility. Mobility in both countries is far from being a marginal phenomenon, since it concerns more than one out of two individuals.

Job-related mobility is distributed differently according to gender. Both in Germany and in France and in very similar proportions, it is principally masculine. ${ }^{7}$ But comparing the two countries reveals a gender distribution that is different with respect to the choice of form of mobility. In France, mobile women are more readily $L D C$ s. Mobility requiring regular absences from home - especially nights - (Multi-mobiles or Overnighters) is more of a masculine phenomenon. Men are also more frequent among Recent Relocators. Moving the entire family seems more probable when it is the man who is professionally mobile. Women's professional careers do not seem to give way to changing the family's place of residence, thus ipso facto causing these women's mobility (Bonnet et al. 2008). Contrary to France, the situation in Germany does not show any specific form of mobility for women compared to men. This difference concerning chosen forms of mobility may be due to the fact that mobile French women have children more often than mobile German women do ( $56 \%$ vs. $38 \%$ ). When we consider cohabiting children, the gap is even wider, only $22 \%$ of mobile German women have cohabiting children against $49 \%$ of mobile French women. We can suppose that many French women choose a form of mobility which allows them to come home every day to look after the children. In Germany, women seem to drop out of the labour market when they become mothers and ipso facto are less often job mobile.

7 Among mobiles, 54\% are men and 46\% women in Germany, 53\% men and 47\% women in France. 
As to Overnighters, a group that the second, qualitative part of the article will concentrate on more specifically, it is a type of mobility that is clearly more masculine in both countries ( $80 \%$ in Germany; 78\% in France).

Men and women's job-related mobility also takes on different meanings depending on their partner's participation in the labour market. The Franco-German comparison reveals contrasting realities on that point. First, a general fact should be mentioned: German men (whether they are mobile or not) live with partners employed full-time (37\%) less often than French men do (67\%). Such are the consequences of differing cultural traditions sustained by different social and family policies in the two countries. Education of children is more family-centred in Germany than it is in France; as a consequence, mothers in Germany less often have paid work. Family policies and social institutions did not really encourage mothers' participation in the labour market until recent years. The male breadwinner model still seems to be more common in Germany than in France. ${ }^{8}$

This "general fact" changes radically, however, if we take into consideration men's or women's mobility status. In Germany, mobile men live more often with partners employed full-time than non-mobile men ( $45 \%$ vs. $35 \%)$ and they live less often with unemployed women than non-mobile men (31\% vs. 38\%). This result goes against the general tendency in Germany. But we may suppose - a fact that we will come across again in the qualitative part of the article - that these couples have children less often than others (they may not have children as they are in the younger age categories). In France, the opposite tendency is the case. Although female partners' full-time activity by far exceeds what is observed in Germany, mobile French men live more often with unemployed women than non-mobile men do (22\% vs. $15 \%)$ and less often with full-time employed women $(60 \%$ vs. $69 \%) .{ }^{9}$ Men's mobility in France thus seems more often accompanied by women's pulling out of the labour market. It seems that a more traditional model of conjugal roles takes over when men are mobile (Collet 2010).

Concerning female mobility, results are again not in conformity with the "general facts". Like mobile men, mobile German women more often have partners who occupy full-time jobs $(92 \%$ vs. $88 \%)$ and less often an unemployed partner than non-mobile women (4\% vs. $8 \%$ ). On the contrary, in France, although mobile women are also for the most part in couples where the man has full-time employment, they are fewer compared with non-mobile women ( $85 \%$ vs. $90 \%)$. They live more often with unemployed or parttime employed partners than non-mobile women (9\% and 6\% compared to $7 \%$ and $3 \%$ ) and also than mobile women in Germany do (4\%).

These statistical results are the first signs that job-related spatial mobility interacts with couples' lives in interesting ways. The latter surface in the German-French comparison: Couples with mobile partners are not the same in France and in Germany. Whereas the male breadwinner model is generally more widespread in Germany than in France, mobility seems to reverse the situation. In Germany, couples in which one partner is mobile seem more involved in professional life, whether the mobile is the man or the woman. In France, however, mobility seems to either diminish the partner's involvement

8 Researchers analysing gender and family politics with regard to the welfare state do not classify Germany and France in the same category (cf. Ostner 1998).

9 Distinctions as to part-time employment point in the same direction, but differences between mobiles and non-mobiles are very small and therefore not very significant in either country. 
in professional life or be chosen more often by single earner couples, even when it is the woman who is working for pay and being mobile. The male breadwinner model appears when men's mobility is concerned. We will pursue that line of thought by examining more closely how mobility can be interpreted from the couple's point of view.

\subsection{Job-related mobility concerns the couple as a whole}

Our first results make us think that mobility should not only be considered an individual matter, but a concern for the couple as a whole. As soon as individuals set themselves up in a couple or family, the mobility of one partner affects the professional and private life of the other one. It is however possible to imagine that the mobility of one partner may be the consequence of the other's professional activity, and thus somehow be produced by it. It therefore makes sense to consider the experience of mobility according to whether one of the partners, or both, is/are gainfully employed, and whether the mobile partner (man or woman) is living with a person who is (or not) employed (cf. Table 2).

Among persons living in stable, conjugal relationships,${ }^{10}$ if we consider both bi-active and mono-active couples, mobility concerns approximately one-fourth of all couples in Germany (25.7\%) and one-fifth of them in France (19.2\%). ${ }^{11}$ Mobility accurs more frequently among German couples than among French ones.

Table 2: Mobility in the couple in Germany and in France

\begin{tabular}{|c|c|c|c|c|}
\hline & \multicolumn{2}{|c|}{ Germany } & \multicolumn{2}{|c|}{ France } \\
\hline & Number & $\%$ & Number & $\%$ \\
\hline Bi-active / Dual mobiles & 41 & 3.6 & 21 & 2.7 \\
\hline Bi-active / Woman mobile & 45 & 4.0 & 29 & 3.8 \\
\hline Bi-active / Man mobile & 134 & 11.8 & 75 & 9.9 \\
\hline Bi-active / Non-mobile & 575 & 50.8 & 456 & 60.3 \\
\hline Woman mono active \& mobile & 3 & 0.3 & 4 & 0.5 \\
\hline Man mono-active \& mobile & 68 & 6 & 17 & 2.3 \\
\hline Woman mono-active non-mobile & 38 & 3.4 & 31 & 4.2 \\
\hline Man mono active non-mobile & 229 & 20.2 & 123 & 16.3 \\
\hline Total & 1.133 & 100 & 756 & 100 \\
\hline
\end{tabular}

Source: From the European survey "Job Mobilities and Family Lives in Europe”.

There are generally more bi-active than mono-active couples in both countries. Accordingly there are more bi-active than mono-active couples with at least one partner mobile ( $19.4 \%$ vs. $6.3 \%$ in Germany and $16.4 \%$ vs. $2.7 \%$ in France). Germany has higher scores for each category. Couples who are both bi-active and dual-mobiles are rare in both countries $(2.8 \%)$. The proportion of bi-active couples without mobility is higher in France

10 The question put to the surveyed population was worded as follows: "Do you currently have a stable relationship?" In Germany $79 \%$ of persons between the age of 25 and 54 live in stable relationships and $81 \%$ in France.

11 Couples in which inactive persons are mobile (e.g. Recent Relocator in the last three years) were not included in the table 
than in Germany (60.3\% vs. 54.4\%). This disparity is not only due to the different mobility features of bi-active couples but attests also to the higher proportion of mono-active couples, with or without mobility, in Germany than in France (29.9\% vs. $23.3 \%$ ).

In order to know whether bi-activity produces more mobility than mono-activity, we must consider mobility scores among these two specific populations. Bi-activity increases job-related mobility. In Germany, $27.7 \%$ of the bi-active couples are mobile, whereas only $21 \%$ of the couples with at least one active partner are. In France, the difference is even more pronounced, $21.5 \%$ and $12 \%$ respectively, due to a greater rate of bi-activity,

Do gender differences surface when mobility concerns only one partner? To answer that question, we will look at the various types of couples and consider mainly the gendered characteristics of dual-career as well as mono-active couples in which one of the partners is mobile. Visibly, when mobility enters a couple's life, it is in most cases masculine, among bi-active as well as mono-active couples. Among the latter, and in both countries, there are hardly any mobile women - which largely reflects the fact that in singleearner couples the breadwinner is usually male, independently from mobility requirements. There are more than twice as many bi-active couples with mobile men than with mobile women in Germany and twice as many in France. As mobility requires longer absences from home or intense job involvement, it confirms in a sense that men still seem to be more job-orientated than women. Of course, the latter have been integrated in the job market as much as their partners: $70.2 \%$ of the couples in Germany and $76.8 \%$ in France are bi-active, but family work still seems to be a female affair. It seems easier for men to leave family obligations to their female partners than the other way round, and family policy still contributes to the idea that the work-family balance is a female affair (Lewis 2009). The dominant model seems to be one of couples whose strategy it is to achieve a social standing defined by a better income and a better professional situation for the husband, who benefits from the input and backing of his wife (de Singly 1987). Differences in men and women's educational and professional careers contribute to maintain these more traditional features even when both are equally involved in the labour market. A study of engineers' careers according to their marital status and number of children in France tends to confirm that model (Gadéa/Marry 2000). In Germany, this may be the case in the managerial professions (leitende Angestellte) and even in other professions too. Since parents do not receive much help with their child-rearing obligations from the state (availability of childcare and school schedules) in Germany, the children's education implies that women pull out of the labour market. In order to refine our analysis, we will consider the types of couples in relation to the presence/absence of cohabiting children in the family (cf. Table 3).

Among dual-earner couples in which only one of the partners is mobile, distinctions surface according to gender. Female mobility, which is more frequent in the youngest age group, in both countries, is very sensitive to the presence of children, in Germany particularly. Mobile German women have nearly half as many children as mobile French women. The table confirms once more that in Germany children represent a strong deterrent for female mobility and when they are grown and leave home, it doesn't encourage women to become mobile again - or for the first time - either. But the presence of children also has an effect on men's mobility. Mobile German men, whether they live in biactive or mono-active couples, are less mobile when the children are still at home. In France, a large majority of mobile men have children living with them at home. 
Table 3: Couples' mobility situation and presence of children in daily life

\begin{tabular}{|c|c|c|c|c|c|c|c|c|}
\hline & \multicolumn{4}{|c|}{ Germany } & \multicolumn{4}{|c|}{ France } \\
\hline & $\begin{array}{c}\text { No } \\
\text { children }\end{array}$ & $\begin{array}{l}\text { Children } \\
\text { living with } \\
\text { their } \\
\text { parents }\end{array}$ & $\begin{array}{l}\text { Children } \\
\text { not living } \\
\text { at home }\end{array}$ & Total & $\begin{array}{l}\text { No } \\
\text { children }\end{array}$ & $\begin{array}{l}\text { Children } \\
\text { living with } \\
\text { their } \\
\text { parents }\end{array}$ & $\begin{array}{l}\text { Children } \\
\text { not living } \\
\text { at home. }\end{array}$ & Total \\
\hline $\begin{array}{l}\text { Bi-active dual mobile } \\
\text { couples }\end{array}$ & 46.3 & 29.3 & 24.4 & 100 & 47.6 & 33.3 & 19 & 100 \\
\hline $\begin{array}{l}\text { Bi-active } \\
\text { woman mobile }\end{array}$ & 66.7 & 24.4 & 8.9 & 100 & 34.5 & 48.3 & 17.2 & 100 \\
\hline $\begin{array}{l}\text { Bi-active } \\
\text { man mobile }\end{array}$ & 23.1 & 28.4 & 48.5 & 100 & 18.7 & 70.6 & 10.7 & 100 \\
\hline $\begin{array}{l}\text { Mono-active couples } \\
\text { one partner mobile } \\
\text { (usually the man) * }\end{array}$ & 15.5 & 29.6 & 54.9 & 100 & 9.5 & 81 & 9.5 & 100 \\
\hline
\end{tabular}

$\mathrm{W}$ nation - For Germany $\mathrm{N}=1132 ; \mathrm{V}=.295 ; \mathrm{p}=.000$. For France $\mathrm{N}=754 ; \mathrm{V}=.253 ; \mathrm{p}=.000$.

* The situations of mono-active couples where the woman is mobile are rare: They are only 9 cases out of 74 in Germany (65 mono-active couples with mobile men) and 8 cases out of 44 in France (36 monoactive couples with mobile men) (unweighted numbers).

Source: From the European survey "Job Mobilities and Family Lives in Europe".

Reading job-related professional mobility according to conjugal considerations revealed unmistakably dominant profiles. In both countries, bi-active couples where the men are mobile are the most frequent configuration. Mono-active couples where men are mobile are much less frequent, but when that is the case, there is a visible difference between the two countries: such couples are more than twice as numerous in Germany.

In Germany, women and men's mobility is noticeably more common when they are childless; their rate of mobility drops drastically when they live in a couple with children. In France, compared to Germany, the presence of children seems to have much less influence on female and male mobility and apparently does not put a halt to mobility. French women tend to be mobile when they have children, though to a lesser extent than those who don't. German women are more mobile than French women, but they have fewer children. However, as we shall see in the following section, beyond the reality of numbers, job-related mobility leads to other marital arbitrations, that only a finer, qualitative analysis is able to uncover.

\section{The conjugal management of mobility: An approach in terms of "family career"}

The following results based on the qualitative, French and German studies concentrate on a specific type of geographic professional mobility, namely the Overnighters. These studies give us the possibility to explore this mobility type further, by analysing how it enters into a couple's and a family's plans.

From the outset, it was our assumption that decisions that are to be taken in professional life - including mobility and being away from home - are not made individually, 
but take into account the insertion of the individual into his/her larger family circle. In particular, these decisions are negotiated by the couple. These decisions imply the family dimension as much as the professional dimension. For this reason, we suggest analysing them in terms of "family careers" by adapting the concept of 'career' as conveyed by E. C. Hughes.

The notion of "family career" adopts a resolutely biographical approach. It refers to the various stages of family life and intervening changes, the conjugal events - falling in love, setting up house together, birth or absence of children, separation, death ... - and the various activities surrounding them, particularly both partners' professional activities. Family careers, apprehended from the point of view of both the individual and the couple, are also determined by a family's specific problems, such as those concerning potential conflicts between the couple's family life and their professional careers. What is more, each partner's professional career may itself be marked by the stages that punctuate their family life, and by the negotiations and adjustments between partners concerning the way family life and their respective professional lives should proceed. That perspective means questioning - without forgetting gender relations - the more or less strong connection between each partner's definition of family "success" and their professional achievements, e.g., the priorities given to the family and/or the professional sphere by each partner individually or jointly by both partners (for a more detailed presentation, see Bonnet et al. 2006b).

The second part of this article will thus give us the opportunity to present the different ways these family careers have been constructed, especially by looking at the manner geographic mobility is negotiated with relation to their plans for their family or their couple. Job-related mobility makes it possible to observe work-life balance more intensively. Different ways of dealing with mobility in relation to commitment to the job are the main explanatory factor. We distinguish two typical configurations of family career, which are handled here as ideal types. The couples' empirical behaviour corresponds more or less to one of the two types. The first type integrates mobility in the family project, whereas in the second, mobility is imposed on the couple by one of the partners. ${ }^{12}$ Each type is analysed in accordance with to the man's or the woman's mobility and to the couple's bi- or mono-activity.

In terms of family careers, we developed this typology based on data from the qualitative French study and have attempted to reconsider the results of the qualitative German survey in light of the former study. Obviously, the results of the German qualitative study were not produced with the same perspective. The German results placed more emphasis on differences, such as between Shutters vs. other forms of mobility (Long-distance commuters. Relocators, etc.), than on conjugal negotiations. ${ }^{13}$ We nevertheless assumed that the two types of family careers (mobility integrated in the family plan vs. mobility imposed by one of the partners) existed in both countries. They are not expressed in the same way, depending on whether one considers men's or women's mobility, especially considering that Over-

12 These two configurations do not cover all possible conjugal arrangements due to mobility.

13 In the German survey, shuttles stood out compared to the other mobility types (LDCs, Relocators, etc.) and to non-mobiles, due to the fact there were many women among them, to both partners' high education levels (more than the Abitur), and to a relatively small number of children (Schneider et al. 2001: 123). 
nighters in Germany usually have no children, whereas those interviewed in France do. ${ }^{14}$ The comparison introduces a more qualitative aspect into the analysis of mobility, however, therefore allowing us to reflect more thoroughly on the situation as a whole.

\subsection{Geographic mobility integrated in the family plans}

For the couples corresponding to this first type of family career, the mobility of one of the partners, or even of both, is a project that was jointly negotiated by them. The partners are usually part of a dual-career couple and the evolution of both their careers is viewed in a relatively egalitarian manner, as is the sharing of their domestic and educational obligations. Their negotiations are explicit, favouring adjustments between the family and professional spheres of each partner. Communication is omnipresent, including when the mobile person is far away from home (e.g. frequent use of the telephone). Decisions and management are thought out by the couple as one, and negotiations take on the appearance of an exchange in which the satisfaction of each partner is uppermost.

The two studies reveal that the couples are strongly involved in their professions. It is almost inconceivable for them to make professional concessions in view of conjugal and family choices. The couples whose experience corresponds to this configuration are relatively homogamous, with both partners having gone through higher education and occupying positions of intermediate or upper management and executive rank. Mobile men are very much into their work, although they do take their partners' professional ambitions into consideration. The bi-localisation of the partners during part of the week was made necessary because the women cannot or do not wish to leave their job. Mobile women had also gone to university and were to the same extent as the men, very involved in their professions.

"Then I was offered the position at B. (...). But at the same time, we decided to live together in E., we had made up our minds for E. (...). It was obvious we wanted to live together, but it also went without saying that neither of us would leave our job or accept a less interesting position. In theory, we wanted it all." (German study, Schneider et al. 2001: 128)

For these mobile men and women, the obligation to become mobile was accepted out of respect for the other's profession. This is a far cry from the classical, sexual domination in the professional sphere. The couples make do with the mobility situation by trying to make it as free as possible (adapting their schedules), and by appreciating its advantages, which allow each one to express their individuality better.

"The reasons were as the following: I have a special profession that doesn't allow me to work where I want (...), if I decided to settle there, it's because I had the opportunity to have a regular job. I only had a limited, part-time job here, so when I had the chance to get that stable position, I left for Bavaria. (German study, Schneider et al. 2001: 132)

But in other cases, the geographic mobility of one is plainly experienced as a constraint that disturbs the family equilibrium and which they wish would end as soon as possible

14 The comparison cannot be carried out exactly in the same terms because we do not have the original material used in the German study at our disposal. Thus, we have compared results drawn from the research report. 
(e.g., by a transfer), although when it does end, it is often to the detriment of the quality of life (e.g., in France, being forced to return to the Paris region)

“(...) we didn't think too much about distance because as months without work piled up, we told ourselves that there would be more job offers in and around Paris so little by little we grew used to the idea of his returning to Paris, and when we threw in the balance the fact he couldn't stand being inactive any longer, we decided it was better to put up with distance. I told myself I preferred seeing my husband only weekends if he felt better, etc. than to see every evening a husband who doesn't feel well, who's depressed." (French study, Bonnet et al. 2006a: 145)

The idea of "give-and-take", of "it's only fair", is sometimes also present when people manage their professional careers. The professional careers of both partners as well as domestic and/or educational obligations are alternately given priority (i.e., the partners take turns). In order to make mobility easier, the temporary retreat of one of the partners from the labour market could be taken into consideration. This period in life could offer the opportunity for training or continuing education, for taking a vacation or for dedicating oneself to more artistic or manual activities. Sharing domestic chores remains egalitarian. In these specific cases, their professional careers are not given priority simultaneously but consecutively. In absolute terms, it signified that it would eventually be the most work-involved partner's turn to cease working, In an American study, that attitude was called "scaling back" (Becker/Moen 1999).

"So, well it's true that there is an aspect... I think it's necessary to be structured as a couple and to have an autonomous way of looking at the couple from the start, which was the case with us. When I went back to school, we practically had a contract, because when we had started living together, he was a conscientious objector, after that he created an association, he worked half-time for a minimum wage and I had the real job, and it had always been agreed that the day you want to do something else, we swap. I realize it's also because we had a sort of contract of that sort that I was able to do all that". (French study, Bonnet et al. 2006a: 128)

The family career in this configuration is built on the basis of a strong commitment to the job. Both partners are absorbed in their professions and seek professional self-fulfilment both for themselves and for their spouse. Decisions are made together and aim for an overall balance between the professional and the familial.

This sort of conjugal negotiation is present in both countries. A difference between the two national contexts, however, resides in the fact that the couples in France have one, or even two children, whereas in Germany, the couples in this first configuration of mobility seem rather not to have any, especially when the mobile partner is the woman.

This state of things can be found in the quantitative results presented in the first part of our article and seem to indicate that bi-active couples facing a mobility situation in Germany obviously have fewer children than in France (see Table 3). It is as if the German women in this configuration chose their professional career over having a family.

"I don't know how to reconcile having a child and working. Right now, it wouldn't be possible, since I'm constantly on the road and I don't know how that could change right now. We'd have to cut down on things and right now it's clear for me my job is the most important. If I have to stay home and be a housewife to have a child, if that's the condition, I don't want to have kids!" (German study, Schneider et al. 2001: 170). 
Mobile women in France have children in greater proportions; they do however mention the difficulties they have to reduce their primary role in the home and with the children, despite the relatively equal sharing of domestic and family obligations they have set up with their partners. We will see below how people experience these situations when one of the partners asserts his/her mobility more persistently.

\subsection{Mobility imposed by one of the partners}

In this second configuration of family career, a more individualistic option seems to take precedence and the professional concerns of one of the partners predominate in the couple. In this case, mobility is in fact imposed, to the extent that negotiation about that professional choice was practically non-existent. The professional involvement of one of the partners is so strong that the conjugal and family project is pushed into second place. But the impact on the couple's relationship is quite different, depending on whether the mobility is masculine or feminine.

\subsubsection{When the masculine choice is imposed...}

The masculine career is here at an advantage. The men concerned are the principal breadwinners and have invested the role of family provider. They are very caught up in the professional world and occupy functions that include considerable responsibility. They enter geographic mobility on a national, and sometimes international, scale (missions abroad). Geographic professional mobility gradually sets in as their career advances and their responsibilities multiply.

Wives largely back up their husbands' careers by taking upon themselves the domestic organisation of the household and the children's education. That responsibility "goes without saying"; it seems to be barely discussed by the couple. Certain spouses gave up their professional activity at the birth of the first child, or of the second or third child, and took responsibility for running home and family on a daily basis. Putting an end to their professional career goes along with their husband's ascending mobility. For the couple, relatively asymmetrical realities emerge. The man sees to the economic needs of the family, which justifies his many absences from home. For certain women, their partner's sometimes considerable income allows for a very comfortable way of life and appreciable financial advantages. These are regarded as a just reward for having accepted to be responsible for running the family.

"After the birth of our third child, my wife did not go back to work at the end of her maternity leave. And since then, she never went back. She felt that with three kids and a very absent husband ... . Today, we've more or less found the right balance, it's fragile, but ... I think there are times she found it very difficult. Three small children, and I was gone four whole days, it was really a difficult time. Today, I'm away for shorter periods, but I'm very busy here between the mayor's office and the region. (...) Since we moved, we have a beautiful house with a large garden, my wife takes care of the garden." (French study, Bonnet et al. 2006a: 115)

Mobility situations such as this one develop gradually, while the couples are already living together and the children already born. Mobility and male careers are jointly dealt with over many years. The wives often feel it is their destiny. Less well-educated than 
their husbands, less committed to their job, they have fewer arguments to negotiate more consideration for their professional commitment. Some of them conform to predominant gender roles and deliberately invest the family and domestic sphere. When the woman has not managed to come to terms with that harsh sexual division between each partner's field of commitment (often unforeseen at the beginning of the couple's relationship), they separate.

"I still think that the fact I wasn't home - it's clear that was what they reproached me most for during the divorce - so I well know that I shouldn't make the same mistakes again. But you must also understand that when you're away the whole week, you don't necessarily want to make an effort on week-ends, you tend to want to rest a little, now I do really try to be a bit more available during the weekend" (French study, divorced, mobile man living in a couple again, Bonnet et al. 2006a: 116).

The Shuttles interviewed in the German study do not seem to correspond to that sort of imposition of male mobility. Living more often in dual-earner and childless couples, ${ }^{15}$ they are, on the whole, described as acting according to their conjugal ideal - i.e. a greater independence for both - they correspond more to the first configuration. The mainbreadwinner model, noted in the statistical analysis, is not present - or more rarely among Shuttles, it is found more readily among Relocators or LDCs (Long-distance commuters). The statistical analysis also revealed that French women apparently choose this sort of mobility less than men do, perhaps precisely because they have children. German women and men, when they are Overnighters, do not (or much more rarely) have children and thus are not in this conjugal configuration, even though the model is virtually just as possible in Germany as in France.

\subsubsection{Women's choice: A form of compensation}

Contrary to the situation described above, in this specific configuration of the family career, the woman's professional career is given priority. She imposes it on her partner, just as she imposes it on the family unit. Contrary to couples in which it is the man who is mobile (2.2.1), the partners of mobile women are not in an inferior position professionally, they are as committed as the women. Women's unilateral decision in favour of mobility has no direct consequence on their partner's professional involvement.

It is as if these women were compensating for a situation experienced as an imposition. In Germany, this "revenge" resembles a refusal of the maternal role, as mothers are traditionally more often committed to family involvement and jobless. Female Overnighters declare the same professional commitment as the men, they are liable to "do their thing" without really negotiating their decision in favour of mobility with their partner. They have no children to take care of.

"She had a limited contract, she was supposed to work eleven months, for me it wasn't a problem, I was open and I made do with her being away. Then they offered her another one for a year, I said OK, it's good to have as much experience as you can in that profession. But my wife didn't tell me, or only when she was on the verge of signing, that they had offered her a permanent contract. It was

15 Socio-demographic data of the German survey reveal that only $32 \%$ of the Shuttles have children. All the other categories present in that survey have children in higher proportions: $69 \%$ for the Inactives, $58 \%$ of the $L D C \mathrm{~s}$, and $67 \%$ of the Relocators. (Schneider et al., 2001: 123). 
a bit hard to take, when I understood that it was going to be like that for a long time ..." (German study, female shuttle's partner. Schneider et al. 2001: 132).

A decision in favour of mobility not backed up by a negotiation between the partners may alter the quality of their relationship. The mobile partner described the situation differently:

“At first, I had to work in the West for two years, but now I've been there for three years, it wasn't supposed to be like that at the beginning. My partner has problems with that all the time, he has the feeling that his 'girlfriend' is coming to see him for the weekend, whereas I'm coming home to my husband. I'm not a visitor, it's the other pole in my life". (German study, female shuttle, Schneider et al. 2001: 132).

Female Overnighters in France do not have the same profile. It is rather as if they were getting their own back with respect to some previous family situation. Being in their forties for the most part, they have teenage or nearly grown-up children. The children's age is a decisive element in a career strategy deemed possible only because the children are big. These women are in an age group in which they judge a professional change or development to still be possible, but only if they wait no longer.

Disposing of good intellectual aptitudes and a strong involvement in their work, mobility becomes the sign that they are asserting themselves in the professional sphere. The male partners accept the changes this mobility brings about in the couple; all the easier to accept when the children are raised and managing the domestic sphere is no longer a major preoccupation. Some of them nevertheless mention feeling frustrated that their wife is doing less in the home and that they must juggle with her lesser availability.

Another important characteristic concerning these women: they all, at one time or another, had seconded their husband in his career and followed him when necessary. We discovered in their testimonies the idea, when making up their minds about becoming mobile themselves, that it was "only fair". But their statements also underlined the fatigue and the burden they experience due to the spatial mobility to which they had consented. The possibility of moving the whole family was seen as inconceivable for both the couple and their partner. It was even less thinkable when the couple had lived in the same place for several years,

It should also be noted that mobile women see the swap that took place in the couple as unbalanced from the perspective of the concessions each partner had to make. They not only had to face the need to prove their decision was legitimate - which men do not always have to do when it is them who are mobile - but they also mentioned the permanent stress and arbitrations they must endure between their professional activity and their life with their partner. The efforts to reconcile the two spheres, sometimes accompanied by a form of guilt related to the choices they made, seem to weigh more heavily on the women than on the men.

"Well, when I'm not there my husband gets along fine, our daughter comes home from time to time, she's studying in M., so my husband and our son heat up the food I left in the freezer. My husband sometimes turns on a machine, but to tell the truth (she hesitates...), they don't get along... Sometimes, when I come home, there's a bad atmosphere, I can feel nothing is right, they can't communicate, or worse, they fight, my son has terrible problems in school, we don't know what to do anymore, and my husband is beside himself" (French study, Bonnet et al. 2006a: 125). 
This second configuration of family career is built on strong commitment to the job by one of the partners. It casts more light on typical gender divisions. Mobility imposed by the man does not give way to the same sorts of conjugal negotiations as mobility imposed by the woman. Male mobility is imposed de facto, it may even impose professional choices on the partner; female mobility is more careful. If female mobility is not negotiated, it is because women do not feel it is legitimate. They know they will not obtain their partner's approval, or they are looking to re-establish a personal equilibrium with respect to a previous conjugal or family situation. The positioning of mobile women in the German study appears more radical because they seem to be choosing between a professional career or investing in having a family.

Job-related spatial mobility made it possible to observe the effects of different family careers. When the latter are based on cooperation and respect of each one's job, one partner's mobility is not due to gender role distribution in the couple. But in the opposite case, when mobility is more an individual feature, we observe a rather classical role distribution in case of men's mobility and a kind of inversed role distribution in case of women's mobility. Female mobility is closely associated with family development, mobile women tent to have few or no children, especially in Germany. In general, it was interesting to see that job-related spatial mobility very clearly exacerbates negotiations on gender divisions and men's and women's different commitment to job or family.

\section{In lieu of a conclusion: Reconciling professional and family life}

Overall, looking at the different types of job-related mobility points to more frequent mobility in Germany than in France. German mobiles, more frequently than French mobiles, tend to be in recurrent forms of mobility (returning to the same place), especially $L D C$ s. This difference may be due to the federalist organisation on the one side and centralized organisation on the other; distances between the working place and residence are less important in Germany than in France.

As to gender distribution, men are more mobile than women in both countries, but French women do not give priority to the same types of mobility that German women do. This difference clearly relates to the different family situations in both countries. Mobile French women have children more often than mobile German women do, so they tend to choose those forms of mobility allowing them to reconcile work and family more easily.

Our analysis according to conjugal logics shows that bi-active couples in both countries were more often confronted with mobility than mono-active couples. We may thus deduce that bi-activity increases, at least in part, spatial mobility for professional reasons. It also seems, particularly in Germany, to modify the way one relates to family projects.

It was interesting to observe that mobility in the couple radically changes general features in Germany and France with regard to couples' mono- or bi-activity. In general, German families still tend to choose more often a man's mono-active job involvement than families in France do. On the other hand, one observes mobility in Germany in biactive couples without children more often than in France. There, due to the presence of children, one observes a real "traditionalising" effect produced by job-related mobility: In case of men's mobility, French women work part-time or not at all. Job-related spatial 
mobility makes couples' arrangements visible and influences both: job involvement and the decision to have or not to have children.

The Franco-German comparison especially revealed that the mobility of one or the other partner seems to have a bearing on the choice to embark (or not to embark) on life as a family. Mobile interviewees, men and women, have children more readily in France than in Germany. While German couples confronted by mobility seem, more than in France, to choose between a professional and a family commitment, as if it was difficult to reconcile the two.

The qualitative studies allowed us to delve into the ways couples actually experience mobility. Choosing a situation of mobility goes together with a certain number of adjustments between family and professional life, and with the quest for a sometimes delicate balance between each partner's professional and family objectives. The work-family balance appears all the more fragile when there are children on the scene. The solution then may consist in not having any. While the French study reveals the difficulties of reconciling the two spheres in daily life, the German study illustrates another facet of compromise: making up one's mind for or against founding a family. The structural conditions and different family and maternal conceptions ${ }^{16}$ in the two countries lead to different consequences in situations of mobility.

While the quantitative survey allowed us to circumscribe the reality of job-related geographic mobility for men and women, the qualitative studies were able to make sense of the noted gender differences by showing, in particular, that male-female relations are underpinned by different conjugal conceptions and adjustments. Nevertheless, the two methodological approaches, thanks to their complementary nature, allowed us to refine the analysis of gender relations by showing that behind male-female differences, more or less egalitarian ways of perceiving the couple and different family options for achieving mobility may be concealed.

\section{References}

Becker, P. E. \& Moen, P. (1999). Scaling back: Dual-earner couples work-family Strategies. Journal of Marriage and the Family, 61, (4), pp. 999-1007.

Boltanski, L. \& Chiapello, E. (1999). Le nouvel esprit du capitalisme. Paris: NRF Gallimard.

Bonnet, E., Collet, B. \& Maurines, B. (2006a). Mobilités géographiques professionnelles et carrières familiales. Rapport de recherche PUCA (Plan Urbanisme Construction Architecture), Paris: Ministère de l'Equipement.

Bonnet, E., Collet, B. \& Maurines, B. (2006b). Working away from home: Juggling private and professional lives. In: W. Canzler, V. Kaufmann, \& S. Kesselring (Eds), Tracing mobilities. The cosmopolitan perspective in mobility research. Hampshire: Ashgate, pp. 141-162.

Bonnet, E., Collet, B., Dragus, C., Maurines, B. \& Orain, R. (2008). France - Job mobility bridges regions in centralised France. In: N. Schneider \& G. Meil (Eds), Job mobilities and family lives in Europe. Volume I. Relevance and diversity of job-related spatial mobility in six European countries. Opladen \& Farmington Hills, MI: Barbara Budrich Publisher, pp. 65-103.

16 A recent study comparing France emphasises the specific family norms which are different in these two countries: in France for instance childless couples are less accepted socially, whereas in Germany gender roles are more clearly cut out and the decision to have a child depends more on the husband's job position and his ability to be the main "breadwinner" (Brachet et al. 2010). 
Bonnet, E. \& Collet, B. (2009). Les familles face à la mobilité pour raisons professionnelles: des logiques de genre bien différenciées. Recherches familiales, 6, pp. 55-66.

Bonnet, M. \& Aubertel, P. (Eds) (2006). La ville aux limites de la mobilité. Paris: Presses universitaires de France.

Brachet, S., Letablier, M.-T. \& Salles, A. (2010). Devenir parents en France et en Allemagne: normes, représentations. Politique sociales et familiales, 100, (juin 2010), pp. 79-92.

Collet, B. (2010, forthcoming). Berufsbezogene Mobilität und Doppelerwerbstätigkeit in der Familie. Ein europäischer Ausblick, Kongressband des 34. Kongresses der Deutschen Gesellschaft für Soziologie in Jena. Wiesbaden: VS Verlag für Sozialwissenschaften.

Gadéa, C. \& Marry, C. (2000). Les pères qui gagnent: descendance et réussite professionnelle des ingénieurs. Travail, Genre et Sociétés, 3, pp. 109-135.

Hughes, E. C. (1996). Le regard sociologique, Paris: Edition de l'EHESS.

Kaufmann, V. (2002). Re-thinking mobility. Contemporary sociology. Hampshire: Ashgate.

Klammer, U. \& Letablier, M.-T. (2008), Les entreprises face à la conciliation travail et vie familiale : une comparaison Allemagne et France, Recherches et Prévisions, 92, (juin 2008), pp. 73-85.

Martin, C. (2010). Concilier vie familiale et vie professionnelle: un objectif européen dans le modèle français des politiques de la famille? Informations sociales 157, (1), p. 114-123.

Lewis, J. (2009). Work-family balance, gender and policy, Cheltenham: Edward Elgar.

Ostner, I. (1994). Slow motion: Women, work and the family in Germany. In: J. Lewis (Ed.), Women and social policies in Europe: Work, family and the state, Aldershort: Edward Elgar, pp. 92-115.

Ostner, I. (1998). Gender, family and the welfare state - Germany before and after unification. In: E. Kolinsky (Ed.), Social transformation and the family in past-communist Germany. London: Macmillan Press Ltd., pp. 82-96.

Schneider, N. F., Hartmann, K. \& Limmer, R. (2001). Berufsmobilität und Lebensform. Sind berufliche Mobilitätserfordernisse in Zeiten der Globalisierung noch mit Familie vereinbar? Abschlussbericht des Verbundsprojektes des Staatsinstituts für Familienforschung an der Universität Bamberg (ifb) und der Johannes Gutenberg-Universität Mainz.

Schneider, N. F., Limmer, R. \& Ruckdeschel, K. (2002). Mobil, flexibel, gebunden. Familie und Beruf in der mobilen Gesellschaft. Frankfurt/Main: Campus.

Schneider, N. F. \& Meil, G., (Eds) (2008). Mobile living across Europe. Volume I. Relevance and diversity of job-related spatial mobility in six European countries. Opladen \& Farmington Hills, MI: Barbara Budrich Publisher.

Singly, F. de (1987). Fortune et infortune de la femme mariée. Sociologie des effets de la vie conjugale. Paris: Presses Universitaires de France.

Wagner, M. (1989). Räumliche Mobilität im Lebensverlauf. Eine empirische Untersuchung sozialer Bedingungen der Migration. Stuttgart: Enke.

Submitted on/Eingereicht am: 26.04.2010

Accepted on/Angenommen am: 01.07.2010 
Addresses of the authors/Anschriften der Autorinnen:

Dr. Beate Collet, Maître de conférences

Université Paris-Sorbonne

GEMASS research unit (UMR Paris-Sorbonne/CNRS)

Institut des Sciences Humaines appliquées (ISHA)

Maison de la Recherche

28, rue Serpente

75006 Paris

France/Frankreich

E-mail: Beate.Collet@paris-sorbonne.fr

Dr. Estelle Bonnet, Maître de conférences

Université Lumière Lyon 2,

MoDys research unit (UMR Lyon2/CNRS)

Institut des sciences de l'Homme

14, avenue Berthelot

69007 Lyon

France/Frankreich

E-mail: estelle.bonnet@ish-lyon.cnrs.fr 